\title{
Human Resource Development Analysis: Fancy Feet Running Gear
}

\author{
Joy Cooper \\ Texas A\&M University-Texarkana \\ Larry Davis \\ Texas A\&M University-Texarkana
}

\begin{abstract}
This paper analyzes the human resource development components of a small specialty retail company operating in the product leadership vector by examining the components of human resource management. It constructed a cooperation processes between HRD and company management to increase the effectiveness of human resource activities as it navigated through the external and internal HRD process considerations that affect the operation of a specialty retail business within a competitive market in a rural geographical environment.
\end{abstract}

\section{INTRODUCTION}

This paper is an account of a family owned specialty running gear store located in rural Northeast Texas. Since the owners requested anonymity, the hypothetical names within this paper are Mr. \& Mrs. Jay Jordan with an assumed store name of Fancy Feet Running Gear (FFRG). The store operates in the textile apparel footwear and accessories industry and specializes in the sale of a range of specialty running shoes. It also offers complementary apparel; accessories; and gear to support outdoor activities. Its vision to create an environment that enables healthy balanced lifestyles and has a mission to provide customer service and products to people who want to live well.

\section{Current HRD Policies, Processes, and Systems}

The company's current human resource operation consists of the store owners and two employees. Mr. Jordan stated, "Our employees are avid runners. They know our products and how to use them" (Jordan, 2016). He also stressed the necessity to recruit, train, develop, and retain associates that have goals aligned with the organization's mission. The store offers specialized services and product expertise that create a utility not consistently available in larger athletic store chains. One employee is a former military service member while another is enrolled in a patient care program at a community college in the area.

The employee training program is based upon a training model implemented by a larger running specialty chain. The FFRG owners and employees participate in online training offered by vendors. The owners stressed the importance of continuing education and training for staff and making them available while employees are on the clock. Schedules are set to best support the employees as customer service and employee expertise are the forefront of the business. Job requirements include routine running events 
(Jordan, 2016). Appropriate human resources are vital to the specialty retail company operating in a small geographic location.

\section{Firm Strategy}

The demographic segmentation of the specialty store's market provided a distinctive characterization based on various demographic and socioeconomic components. According to the FFRG owners, most of their customers are Generation Xers although the fastest growing segment is the Millennials. Most of the store shoppers are educated and comparison shop. The customer base consisted of an equal balance of male and female customers (Jordan, 2016). According to Naver, Slater, and Tiete (1998) the psychographic segmentation of a market can be categorized into similar social habits. The feedback gathered from owners, employees, and customers reflect a customer base that has similar social habits and health-driven attitudes and lifestyles.

Figure 1 below depicts a comprehensive view of owner, employee, and customer perspectives. According to Treacy and Wiersema (1995), product leadership represents the continuous search for the best product. The authors describe this type of organization as continually pushing its products into the area of the unknown or the highly desirable. Employees express the ability to be creative, conduct research and have a level of autonomy. The store products and brands are high quality that is reflected in the higher priced shoes and accessories that align with customer expectations in the product leader vector. Although the operational excellence is not the highest ranked among the three vectors, shoppers are attracted to the convenience of local shopping. The specialty store appears to recognize emerging needs of the target market and assess customer response to the organization's strategic decisions.

\section{FIGURE 1}

\section{THE SPECIALTY STORE'S PRODUCT LEADER ORGANIZATION VECTOR}

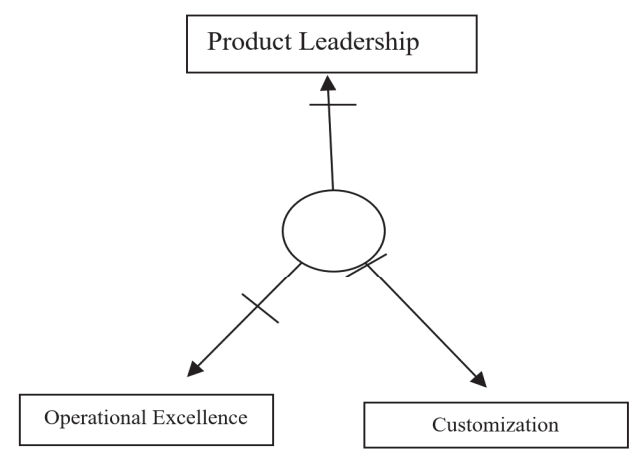

Figure 1. MPRC Product Leader Organization Vector

\section{TALENT MANAGEMENT POLICIES AND PROCEDURES}

Human resource development tactics assist organizational leaders to gain a sustainable competitive advantage through strategic utilization of people. The human assets of an organization are a source of competitive advantage for product leader organizations. Unlike operational excellence firms, product leader organizations look to invest in their human resources because they know that if managed effectively, those investments will yield stronger organizational performance. Large and small companies have opportunities to develop and utilize the talents of employees. Human Resource Development (HRD) practices assist companies to achieve goals and objectives. The following HRD competencies are critical to product leader organizations in order to make the most of employee talent. 


\section{Recruiting and Hiring}

Recruitment and hiring are critical to product leader organizations. Recruitment by nature involves marketing that reaches beyond selling. The specialty store must employ sales tactics that will result in customer satisfaction with the product and customer service. Effective recruiting for a product leader organization will produce similar results. Recruiting tactics for the specialty retail store should attract individuals who will be able to efficiently meet company objectives.

Recruitment methods for a product leader vector will encompass greater innovation and higher qualification thresholds as compared to the methods adopted by an operational excellence organization. Locating sources of qualified applicants is important for a small specialty store in order to deliver specialized customer service. According to McEntire and Greene-Shortridge (2011), employee referrals are one way that top performers are identified. The retail store employees possess specialized knowledge of running techniques and products the target market desires. Therefore, current store employees can serve an important role in the recruitment process by actively soliciting applications from their friends, peers, and running club members.

Additionally, the small specialty store should consider event recruiting. The small specialty retail store has a relationship with product venders that host a weekly $5 \mathrm{~K}$ event that position the store owners and employees with an opportunity to recruit from runners that attend the events. Organizations in the product leader vector engage in hiring practices such as passive candidate recruitment. Passive candidates, as opposed to active job seekers, are typically employed and not actively seeking a new job. This type of recruitment is better aligned to product leadership versus the active job seekers, committed to finding another job that may be attracted to operational excellence companies.

\section{Training and Development}

The recruitment and selection of employees represents the initial stages in building an effective workforce. An effective training program is the heart of a continuous effort designed to improve employee competency and organizational performance. The superior value of the retail specialty store does not reside solely in style and comfort of the running shoe. Customers expect superior product performance that meets or exceeds their expectations. An effective training program provides product leadership organizations with skills and knowledge to push performance boundaries. Sound training objectives and selection methods afford product leader companies similar to the specialty running retail store, the ability to provide continuous innovation from one product cycle to another.

An organizational needs and task analysis will assist the small specialty retail store with the creation of a training and development plan. Employees must be provided with necessary training in order to develop and strengthen their skills as consumer relationships in this vector are not one-time transactions. Product leadership organizations specialize in satisfying unique needs through cultivating relationships with consumers. An intimate knowledge of the customer allows organizations to provide support to achieve desired value from their running products and training services.

Once the training needs are assessed, the organization should consider the culture necessary to inspire creativity to enhance learning. The owners and employees of the specialty retail store are currently participating in weekly product training to remain abreast of the running shoe products and accessories. According to store owners, training techniques such as modeling, practice, and feedback are being utilized. The owners should also consider goal setting, employee feedback, and other evaluation methods to ensure the training is effective and addresses desired objectives.

According to Tracey and Wiersema (1995), employee development techniques can influence creativity in product leadership organizations. The development of information and knowledge regarding interrelationships and influence among creativity, product value, and performance will assist MPRC with optimizing their investment in human capital (Walberg \& Stariha, 1992).

\section{Coaching and Mentoring}

Management development consists of all learning experiences provided by an organization resulting in improved skill and knowledge in current and future leaders. Mentoring is described by Mondy and 
Martocchio (2016) as an "approach to advising, coaching, and nurturing, for creating a practical relationship to enhance individual career, personal, and professional growth and development" (p.259). To successfully operate within the product leadership vector, store mentors should foster and guide customer focus habits and effective team building and collaborative efforts.

Given the specialty store is a small business, the following definition is suitable for their organization. According to Mondy and Martocchio, (2016).), coaching is often considered a responsibility of the immediate boss, who provides assistance, much as a mentor. The coach has acquired a greater level of expertise than the apprentice and is in the position to offer wise advice to guide decision making. Given the emphasis of sustainable and consistent customer service and interaction, coaching and mentoring are important HRD aspects for the small specialty running shoe store.

\section{Appraisal System}

An effective performance appraisal system for the small specialty store will support a creative work environment that is encouraging of employees to perform to the best of their abilities. A traditional performance appraisal process is typically performed annually by a manager. It is designed to assist employees in understanding their roles, objectives, expectations, and acknowledge performance success. It is critical to distinguish the performance appraisal process in product leader organizations due to the motivational potential this system has for the specific type of employee desired. In an operational excellence organization, this system is more likely used to focus low cost and possibly disengaged labor on specific transactional tasks. As previously mentioned, in a product leader organization like the small family owned specialty store, employees can be a real source of competitive advantage. This is primarily driven by the fact that there exists some level of intrinsic motivation if selection procedures are effectively in place. The appraisal system can reinforce this intrinsic motivation if it is a collaborative process that deeply involves these valued employees. Further, having a portion of performance discussions focus on true growth and development will allow the organization to align with the individual values of employees.

The appraisal system implemented by the specialty store should coordinate and focus the staff on delivering the organization's mission. A successful appraisal program will support employee entrepreneurship and creative thinking. If used properly, the appraisal system will enable the store with the ability to measure and reward new product or service success. Additionally, the system and managers will refrain from punitive actions that could stifle experimentation necessary in the product leadership vector.

Table 1 below shows characteristics of performance standards that support the product leadership vector. The performance appraisal system should be directly linked with other HR functions and provide a record of performance based on identifiable objective criteria.

TABLE 1

\section{PERFORMANCE STANDARDS CHARACTERISTICS}

\begin{tabular}{|l|l|}
\hline Strategic Relevance & Individual standards directly relate to strategic goals. \\
\hline Criterion Deficiency & $\begin{array}{l}\text { Standards capture all of an individual's contributions and } \\
\text { creative efforts and does not penalize failed creative efforts }\end{array}$ \\
\hline Developmental & $\begin{array}{l}\text { The performance appraisal program should be developmental, } \\
\text { inclusive, and supportive of organizational strategy changes. }\end{array}$ \\
\hline Reliability and Consistency & $\begin{array}{l}\text { Standards are quantifiable measurable, stable and calibrated so } \\
\text { managers ensure employee appraisals are in line with one } \\
\text { another. }\end{array}$ \\
\hline
\end{tabular}

Mondy \& Martocchio, (2016). 
A successful appraisal system within a product leadership vector should balance managers' observations and opinions with established performance standards that consider internal and external views. Additional sources may also prove to be successful for the small specialty store such as recognition of team accomplishments. A system that seeks evaluation from external sources, such as customers, is another consideration supportive of an innovative environment that thrives on intimate consumer relationships.

\section{Compensation and Rewards}

Product leadership companies such as the specialty store should reward employee innovation, creative capacity, and new product and/or service success. An organizational reward system for a small business delivering exceptional customer value should encourage cooperative employee efforts rather than competitive ones. The specialty store's mission is to deliver quality customer experiences. A reward and incentive plan strategy is necessary for the store to attract and retain top-performing employees.

The specialty running store should establish creative, flexible, challenging, and achievable standards. A successful incentive plan should reward employee commitment to organizational standards by paying premium wages when company expectations are satisfied. The objective of a successful compensation and reward program is to improve employee work satisfaction. A survey from Ghazanfar, Chuanmin, Khan, \& Bashir, (2011), showed employees who were satisfied with their compensation plan were more likely to be satisfied with the jobs.

Gilley, Boughton, \& Maycunich, (1999) outlined creativity in HRD as a reward strategy to help enhance employee commitment in addition to long-term solutions, entrepreneurship, leadership, performance growth and development, teamwork and cooperation, and loyalty. The specialty store should have a reward system that balances work with lifestyle. The small business should consider alternative benefits other than cash incentives as healthy lifestyles are the foundation of their mission. The small company has an opportunity to allow employee involvement to establish flexible work arrangements and other company rewards.

\section{Retention}

HRD measures for product leadership companies involve the human assets that support the company's sustainable competitive advantage (Muthuveloo, Basbous, Ping, \& Long, 2013). The store creates value that translates into organizational initiatives. Attracting and hiring employees is only half the battle. The store must have an ongoing strategy to retain valued employees. Successful retention strategies prevent employees from seeking employment elsewhere. All HRD topics are important to a retention strategy. For the small specialty store, retention is especially critical due to the small size of the organization. Losing just one employee reduces capacity beyond the owners by $50 \%$. In addition, with investments in human resources being a critical sustaining strategy for product leader organizations, protecting that investment through thoughtful retention strategies is essential. With the type of employee needed to sustain product leader organizations, consideration of employee equity programs are worth considering. Reichheld (1996) noted that loyal employees prompt loyalty among customers, customer retention, and increased growth over competitors. Longevity with a company builds a sustainable competitive advantage as employees become more familiar with the business and develop customer relationships that build customer loyalty as staff remain with the business. Chow et al. (2006) adds longtime employees accumulate efficient skills necessary to deliver high quality services found in successful product leadership companies.

\section{Corporate Social Responsibility and Sustainability Goals}

FFRG owners are avid supporters of military service members. They consider doing work that focuses on efforts beyond the bottom line. Their philanthropic mission to combat PTSD is evidenced by the bi-weekly running sessions with veterans to enrich the lives of soldiers with physical and social activity. Demonstrating such social responsibility efforts that employees are encouraged to engage in builds intrinsic rewards, such as camaraderie, that employees can receive from teamwork is beneficial. 


\section{CONCLUSION}

Effective HRD design is critical to the specialty store's pursuit of product leadership and sustainable competitive advantage. The store leaders operating in a product leadership vector have a vested interest in inspiring, protecting, and expanding the business. The specialty running shoe store will need to devote above average resources to the human assets of the business in order to attract hire, recruit, train, develop and retain quality employees.

\section{REFERENCES}

Ghazanfar, F., Chuanmin, S., Khan, M. M., \& Bashir, M. (2011). A study of relationship between satisfaction with compensation and work motivation. International Journal of Business and Social Science, 2(1).

Gilley, J. W., Boughton, N. W., \& Maycunich, A. (1999). The performance challenge: Developing management systems to make your employees your organization's greatest asset. New York, NY: Perseus Books.

Jordan (2016, October 6). Owner. (J. Cooper, Interviewer)

McEntire, L. E., \& Greene-Shortridge, T. M. (2011). Recruiting and selecting leaders for innovation: How to find the right leader. Advances in Developing Human Resources, 152342231142471

Mondy, R., \& Martocchio, J. J. (2016). Human resource management. Human Resource Management, Global Edition.

Muthuveloo, R., Basbous, O. K., Ping, T. A., \& Long, C. S. (2013). Antecedents of employee engagement in the manufacturing sector. American Journal of Applied Sciences, 10(12), 1546.

Reichheld, F. (ed.) (1996). The quest for loyalty: creating value through partnership. Boston, MA: Harvard Business School Press. Treacy, M., \& Wiersema, F. (1995). The discipline of market leaders: Choose your customers, narrow your focus, dominate your market. Basic Books.

Treacy, M., \& Wiersema, F. (1995). The discipline of market leaders: Choose your customers, narrow your focus, dominate your market. Basic Books.

Walberg, H.J., \& Stariha, W.E. (1992). Productive human capital: Learning, creativity, and eminence. Creativity Research Journal, 5, 323-40 